Part 5. The IAU and its relation to diverse geographical regions of the world 


\title{
Germany's difficulties in becoming a member of the International Astronomical Union
}

\author{
Roland Wielen \\ Astronomisches Rechen-Institut \\ Zentrum für Astronomie \\ Universität Heidelberg \\ Mönchhofstrasse 12-14, D-69120 Heidelberg, Germany \\ email: wielen@ari.uni-heidelberg.de
}

\begin{abstract}
After the foundation of the International Astronomical Union (IAU), it took nearly 32 years until Germany became a national member of the IAU. This unfortunate delay was due to both international politics and discussions within Germany (e.g. about the future role of the Astronomische Gesellschaft). The first Statutes of the IAU of 1919 excluded Germany, Austria and other countries from membership for political reasons. When the IAU Statutes were revised in 1931, Germany's membership was possible, but could not be realized because of financial problems. In the mean time, German astronomers (as individuals) were often able to attend General Assemblies of the IAU as invited participants and to work in IAU Commissions as members. After World War II, Germany became a member of the IAU in 1951, Austria in 1955. In 1962, East Germany was accepted as an additional member. The reunification of Germany in 1990 clarified this situation. Member of the IAU is now one unified Germany.
\end{abstract}

Keywords. IAU membership, IAU adhering countries, Germany, Austria

\section{Problems caused by the first Statutes of the IAU of $\mathbf{1 9 1 9}$}

The IAU was founded in July 1919. The parent organization of the IAU and of other scientific unions was the International Research Council (IRC).

The first Statutes of the IAU from 26 July 1919 (Fowler 1922, p. 219) determine in Section I.2 that the admission of countries to the IAU shall be subject to the Regulations of the IRC. According to these IRC Regulations, there were three catagories of countries. These rules had to be followed by the IAU.

(a) The 'Allied Powers' of World War I as founding members: England, France, USA, and other countries.

(b) 'Neutral Countries' as possible additional members: Holland, Sweden, Switzerland, and others.

(c) Excluded from membership were the 'Central Powers' of World War I: Germany, Austria, Hungary, Bulgaria and Turkey.

The exclusion of the Central Powers was based purely on political motivations and was in obvious conflict with the aim of a really international scientific cooperation. This procedure was strongly criticized by the neutral countries and also by many scientists from the Allied Powers. Some of the these discussions are described by Blaauw (1994) in detail in his book on the early history of the IAU. 


\section{Problems within Germany}

Even if the first Statutes of the IAU had allowed the membership of Germany, such an offer would very probably not have been immediately accepted by Germany. There were strong hesitations within Germany against an IAU membership for various reasons:

(a) The Astronomische Gesellschaft (AG) existed already as an internationally orientated society (see next Section 3). The future role of the much older AG in the presence of the new IAU was unclear and probably disappointing for Germany.

(b) The German-speaking scientists demanded from the IAU (and other Unions) that the German language should be accepted by the IAU on the same level as English and French, as it had been the case at international scientific meetings before World War I.

(c) The membership of Germany in the IRC (as a condition for the IAU membership) was refused by Germany. The IRC was considered as a mainly political body, with a chauvinistic attitude, disregarding the interests of Germany.

(d) The financial situation in Germany after World War I was so difficult that Germany was essentially unable to pay an IAU membership fee.

\section{The Astronomische Gesellschaft (AG)}

The AG was founded in 1863 as an international astronomical society. A survey of the history of the AG is given by Schmeidler (1988).

While the AG certainly had its centre in Germany (Dick 2000), there were many foreign members and officers, for example:

- Otto Struve ('the Elder') from Pulkovo (Russia) was President ('Vorsitzender') of the AG from 1867 until 1878. He had been a member of the Board ('Vorstandsmitglied') of the AG already since the foundation of the AG in 1863.

- Elis Strömgren (Denmark) was President of the AG from 1921 until 1930, and a Board member since 1914 .

- Especially remarkable in our context are the various functions of Arthur Stanley Eddington (England) in the IAU as well as in the AG. He was Vice-President of the IAU from 1925 until 1928, Board member of the AG from 1928 until 1930, Vice-President ('Stellvertretender Vorsitzender') of the AG for three terms from 1930 until 1937, and finally President of the IAU from 1938 until his death in 1944.

Other famous members of the AG from non-German speaking countries were, for example, $\ddagger$

F. Tisserand (France): member 1869-1896†, and sometimes Board member of the AG;

S. Newcomb (USA): member 1873-1909†, sometimes Board member;

H. Poincaré (France): member 1905-1912†;

$\star$ W. de Sitter (Holland): member 1909-1934†;

$\star$ B. Lindblad (Sweden): member 1922-1945, sometimes Board member;

* O. Struve (USA): member 1923-1965†, sometimes Board member;

H. Shapley (USA): member 1925-1945, sometimes Board member;

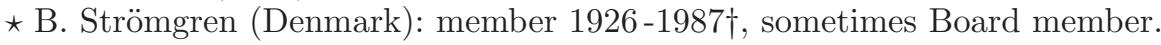

As a side note, we mention that Albert Einstein was a member of the AG since 1921, but he never became a member of the IAU, especially not of IAU Commission No. 1 on Relativity.

Due to the largely international character of the AG, there was (initially) an obvious conflict between the intended roles of the IAU and the AG.

$\ddagger \star$ indicates that he has acted also as President of the IAU. 


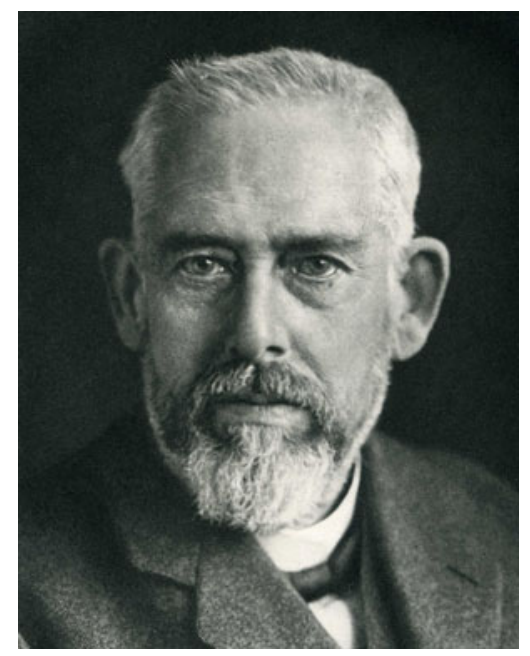

Figure 1. Max Wolf (1863-1932). Director of the Heidelberg Observatory. President of the AG 1930-1932. Chairman of the Elferausschuss 1931/1932 and of the ADA 1932.

\section{Steps of the IAU towards a German participation}

In 1926, the political situation improved significantly. Germany joined the League of Nations (a forerunner of the UN) and became a permanent member of its Council. Both the IRC and the IAU were under some pressure to take into account this new development.

The IAU Executive Committee wrote in a letter of July 1926 to Elis Strömgren, President of the AG, that a possible application of Germany to join the IAU 'will be very welcome to the Union' (Blaauw 1994, p. 84-86). However, the Statutes of the IAU required still the membership of a country in the IRC. Hence this offer was merely a friendly, but effectless gesture of the IAU towards Germany.

A more realistic way to include German astronomers into the work of the IAU was taken in 1928 by W. de Sitter (Holland), President of the IAU from 1925 to 1928. He invited individual astronomers from non-member countries (especially from the Central Powers) to attend the IAU General Assembly at Leiden in July 1928 as guests. Fourteen astronomers from Germany, one from Austria, and two from Hungary followed this invitation.

In September 1931, in an Extraordinary Meeting at London, the Statutes of the IAU were finally revised in order to abolish the former restrictions on the membership in the IAU. Section II.3 of the Statutes now determined that a country not adhering to the International Council (formerly IRC, then ICSU) may adhere (nevertheless) to the IAU (Stratton 1933, p. 295). This revision of the IAU Statutes in 1931 paved the way for an IAU membership of Germany, at least in principle.

\section{Steps of Germany towards an IAU membership}

The revision of the IAU Statutes in 1931 caused a realistic discussion in Germany about the desirability of membership in the IAU.

Obviously, the probable changes in the Statutes of the IAU were known in Germany in advance. On 7 March 1930, an ad-hoc committee was established at a meeting in Babelsberg near Berlin. It was called the 'Elferausschuss' because of its eleven members ('elf' in German). Chairman of the Elferausschuss was Max Wolf (see Fig. 1). Wolf was 


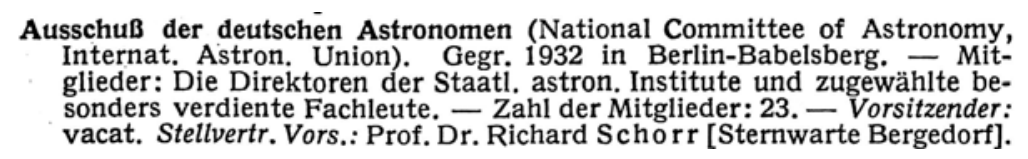

English translation: Committee of the German astronomers (National Committee of Astronomy, IAU). Founded in 1932 at Berlin-Babelsberg. - Members: The directors of the state-owned astronomical institutes and co-opted, specially deserved experts. Number of members: 23. Chairman: vacant. Deputy Chairman: Prof. Dr. Richard Schorr (Observatory HamburgBergedorf).

Figure 2. Information on the 'Ausschuss der deutschen Astronomen' (ADA) from 1933. Reprinted from the compendium Minerva (1933, p. 181, Ed. G. Lüdtke).

\section{Ausschuß der deutschen Astronomen (1932). Mitglieder: Die Direktoren der Staatl. astron. Institute und zugewählte besonders verdiente Fach- leute. Zahl der Mitglieder: 18. - Vors.: Prof. Dr. Richard Schorr [Sternwarte Bergedorf].}

English translation: Committee of the German astronomers (1932). Members: The directors of the state-owned astronomical institutes and co-opted, specially deserved experts. Number of members: 18. - Chairman: Prof. Dr. Richard Schorr (Observatory Hamburg-Bergedorf).

Figure 3. Information on the 'Ausschuss der deutschen Astronomen' (ADA) from 1937. Reprinted from the compendium Minerva (1937, p. 130, Ed. G. Lüdtke).

at the same time President of the AG (from 1930 to 1932). A detailed biography of Wolf is written by Freiesleben (1962).

The task of the Elferausschuss was to discuss the possibility of Germany's membership in the IAU and to negotiate with the IAU about the details of such a joining. A very good overview on the work of the Elferausschuss is given by Wolf in his application to the German Foreign Office in 1931, reproduced by Freiesleben (1962, 165-168). In summary, the Elferausschuss concluded that a German membership in the IAU was very desirable. For financing the IAU membership fee, the German astronomers would have to rely on a support by the government.

In 1932, the Elferausschuss was transformed into a more formal committee, the 'Ausschuss der deutschen Astronomen', abbreviated as ADA. The subtitle of the ADA was already 'National Committee of Astronomy' for the IAU. Some details on the ADA are given in Fig. 2 and Fig. 3 (based on Lüdtke 1933, 1937).

\section{Germany's statement at the IAU General Assembly 1932 at Cambridge (USA)}

Since Wolf became seriously ill in 1932 (he died in October 1932), August Kopff (see Fig. 4) was entrusted with explaining the German position during the Fourth IAU General Assembly, held at Cambridge, Mass., USA, 2-9 September 1932. Sir Frank Dyson (Astronomer Royal, England) was then President of the IAU. The speech by Kopff at this General Assembly is published in full length and in German in Stratton (1933, p. 216). (Fig. 5). Kopff reported that Germany is very much interested in becoming a member of the IAU in the future, but at present, this is impossible for financial reasons (the required 3600 Gold Francs for Germany's IAU membership fee were not available).

We find it very remarkable that Kopff's speech was delivered in German, and that the text was reprinted in German in the IAU Transactions. Was this a signal that German was at least tolerated as a working language within the IAU? Today, this question is, of course, rather obsolete. 


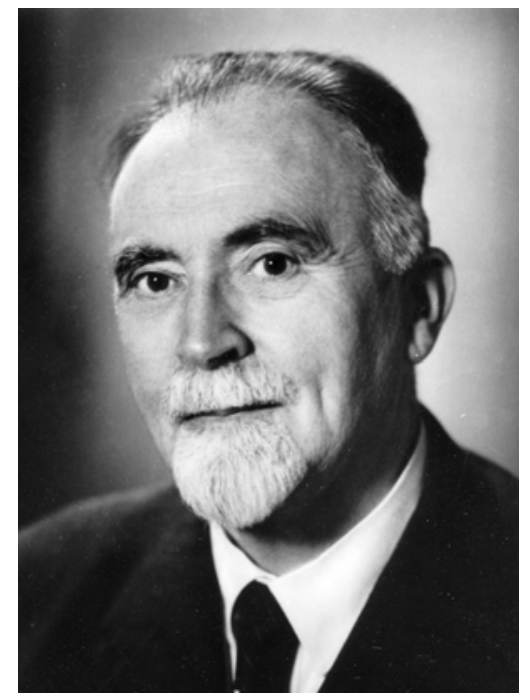

Figure 4. August Kopff (1882-1960). Director of the Astronomisches Rechen-Institut at Berlin and since 1945 at Heidelberg. German delegate at the IAU General Assembly 1932 at Cambridge, Mass., USA. For a detailed biography of Kopff see Wielen \& Wielen (2013).

\section{The period from 1933 to 1939}

During the period from 1933 to 1939, there was no progress in Germany's desired IAU membership. At least, no relevant documents were available to us.

The retardation was most probably caused by a continuing lack of finance. We have no indications that the delay in Germany's IAU membership was connected to the NS government, since other sciences were allowed to apply for membership in their corresponding Unions, e.g. Geodesy and Geophysics in 1937 for the IUGG (Torge 2007). The cooperation of individual astronomers with the IAU was also not hampered by the government or by other organizations.

The IAU was always hopeful regarding Germany's membership. F. Schlesinger (USA), IAU President from 1932 to 1935, said at the Paris General Assembly in 1935: 'I sincerely trust that they (i.e. Germany) will have joined us before our next meeting (in 1938)' (?, p. 276). And E. Esclangon (France), IAU President from 1935 to 1938, still expressed at the Stockholm General Assembly in 1938 'the hope that Germany would soon join the Union' (Oort 1950, p. 318).

During World War II (1939 to 1945), the question of Germany's IAU membership was not acute for obvious reasons.

\section{Solution after World War II}

After the end of World War II in 1945, it took some years to establish a German administration. The Federal Republic of Germany was founded in 1949. This was a basic precondition for discussing and especially for financing a membership of Germany in the IAU. The monetary reform of 1948 (from Reichsmark to Deutsche Mark) had already made the payment of an IAU membership fee in hard currency at least possible.

The IAU General Assembly at Zürich in August 1948 was attended by eight astronomers from Germany as invited guests. Their travel expenses were generously covered by Switzerland. In his speech at the General Assembly, Harold Spencer Jones (Astronomer Royal, England), IAU President from 1944 to 1948, said: 'We look forward to the renewal of collaboration with German and Austrian colleagues' (Oort 1939, p. 16). 
I am going to invite Dr Kopff, whom we are delighted to welcome as a representative of German astronomy, to address the Assembly.

\section{DR KOPFF :}

Herr Präsident, Meine Damen und Herren,

Wie Sie soeben gehört haben, ist vor einiger Zeit ein deutsches nationales Komitee gebildet worden, der Ausschuss der deutschen Astronomen, der sich die Angabe gestellt hat, den Eintritt der deutschen Astronomie in die Internationale Astronomische Union durchzuführen. Der Eintritt ist beschlossen worden; aus finanziellen Gründen allein hat er bisher nicht erfolgen können. Doch werden sich auch diese Schwierigkeiten hoffentlich bald überwinden lassen.

Ich habe den Auftrag, Ihnen die Grüsse des Ausschusses der deutschen Astronomen und aller deutschen Astronomen zu überbringen, insbesondere auch die Grüsse unseres verehrten Vorsitzenden Prof. Max Wolf. Er hat bisher die Verhandlungen über unseren Eintritt in die Union geführt, und zu unserem grossen Schmerz hat eine schwere Krankheit ihn verhindert, selbst hierher zu kommen.

Sie haben bereits zahlreiche deutsche Astronomen zu Mitgliedern in die verschiedenen Kommissionen gewählt, und Sie haben es uns dadurch ermöglicht, noch enger als bisher mit Ihnen zusammenzuarbeiten. Für diese Aufnahme in die Kommissionen möchte ich Ihnen besonders danken. Herzlich danken auch möchte ich Ihnen, Herr Präsident, für die freundlichen Worte, die Sie uns und vor allem unserem verehrten Prof. Max Wolf gewidmet haben.

$\mathrm{Zu}$ unserem lebhaften Bedauern ist es dieses Mal für uns nicht möglich gewesen, in grösserer Zahl in den verschiedenen Kommissionen anwesend zu sein. Aber als der einzige Vertreter aus Deutschland darf ich Ihnen wenigstens im Namen der deutschen Astronomen einen guten Erfolg für diesen Kongress wünschen.

English translation: Mister President, Ladies and Gentlemen, As you have just heard, some time ago a German national committee has been established, the Ausschuss der deutschen Astronomen (Council of the German astronomers), which aims at carrying out the entrance of the German astronomy into the International Astronomical Union. The entrance has been resolved; for financial reasons alone, the entrance could not take place so far. But hopefully it will be possible to overcome those difficulties in the near future.

I have been entrusted with bringing you the greetings of the Council of the German astronomers and of all German astronomers, and especially the greetings from our distinguished chairman Professor Max Wolf. He has conducted the negotiations on our entrance into the Union up to now, but, to our great regret, a grave sickness has prevented him from coming here himself.

You have already elected many German astronomers to members of the various commissions. Thereby you have made it possible for us to cooperate with you even more strongly than before. For this admittance, I would particularily like to thank you. I would also like to cordially thank you, Mister President, for your friendly words which you have addressed to us and to our venerable Professor Max Wolf.

To our great regret, it was this time impossible for us to attend the various commission meetings in a larger number. As the only representative from Germany, I would like to wish you at least in the name of the German astronomers a good success for this congress.

Figure 5. Text of the speech delivered by August Kopff (Berlin) as the German delegate at the IAU General Assembly 1932 at Cambridge, Mass., USA. Source: Stratton (1933, p. 216).

In 1951, Germany became finally a national member of the IAU. Only a few relevant documents on this procedure are available. In the Mitteilungen der Astronomischen Gesellschaft, 1950, p. 3, it is reported from the AG meeting in September 1950 that the entrance of Germany into the IAU is urgently desired ('dringend erwünscht' in German). It was expected that the corresponding negotiations between the President of the AG (F. Becker) and the President of the IAU (B. Lindblad) will achieve the desired effect rather soon. According to Blaauw (1994, p. 162) the IAU General Secretary, Bengt Strömgren, informed the AG in a letter of 17 March 1951 that the IAU recognized the AG as the adhering body for Germany. This letter was acknowledged by the President of the AG in his letter of 24 April 1951. Voting by an IAU General Assembly on Germany's membership was not necessary. 
Although the negotiations were formally carried out by the President of the AG, Friedrich Becker (Bonn), we think that August Kopff (Heidelberg) was the real driving force for the entrance of Germany into the IAU. Kopff was Vice-President of the AG and internationally very renowned.

For the IAU, it was certainly an important signal from the large American astronomical community that Kopff was elected as an 'Honorary Member' of the American Astronomical Society (AAS) in June 1949 during the eighty-first meeting of the AAS (see Gingrich 1949). This honour was especially remarkable, since it was given to a German astronomer only four years after the end of World War II. It certainly indicated that German astronomers should now be fully accepted internationally.

Kopff had the important advantage that he had very good personal relations to three leading persons of the IAU, namely to Harold Spencer Jones (Astronomer Royal, England), IAU President from 1944 to 1948, to Bertil Lindblad (Sweden), IAU President from 1948 to 1952, and to Bengt Strömgren (Denmark), then IAU General Secretary from 1948 to 1952. The reasons for Kopff's good relations to Harold Spencer Jones and Bertil Lindblad are described in detail in some of our books (Wielen \& Wielen 2012, 2013, 2016). Bengt Strömgren was a Board member of the AG from 1939 to 1945. During this period, Kopff was President of the AG.

It is an irony of history that the AG became in 1951 the adhering body for Germany in the IAU. About thirty years ago, the IAU and the AG had been competitors as international astronomical societies (see our Sections 3 and 4). The IAU and the AG seem to have been something of close relatives. Taking up a comparison made by de Sitter at the IAU General Assembly at Leiden in 1928, he considered the diminishing relation between parents (IRC, ICSU) and children (IAU), while Elis Strömgren (President of the AG) called the AG an 'old aunt' (alte Tante) of the IAU. The old aunt (the AG) wished the strong child (the IAU) good luck on its way (Vierteljahrsschrift der Astronomischen Gesellschaft, 63. Jahrgang (1928), p. 254-255).

The formerly persistent problem of financing the IAU membership fee for Germany could also be solved sactisfactorily. The annual costs were (and are) covered by the ministry of the German Federal Government responsible for such international relations.

The other countries from the former Central Powers became also members of the IAU after World War II: Hungary in 1947, Austria in 1955, Bulgaria in 1957 and Turkey in 1967. The slight delay in the IAU membership of Austria (relative to Germany's entrance) was probably caused by financial problems.

\section{Problem during the Cold War Period}

Since 1951, when Germany had become a member of the IAU, the astronomers from West Germany and East Germany were listed for many years commonly under the heading 'Germany', 'Allemagne', or 'Deutschland'. This was e.g. the case at the IAU General Assemblies in Rome 1952, in Dublin 1955, in Moscow 1958 and at Berkeley 1961.

However, the Cold War brought a new problem for Germany's IAU membership. In 1962, East Germany (GDR) was accepted as a new member by the IAU. Suddenly, the IAU had now 'two Germanies' among its members, instead of initially none or later one! East Germany created its own adhering organization. For this reason, the AG, which had still members from East Germany, had to be replaced by the 'Rat Westdeutscher Sternwarten' (RWS), Council of West German Observatories, as the adhering organization of the Federal Republic of Germany for the IAU.

\section{Final solution since 1990}

In October 1990, the reunification of Germany (Deutsche Wiedervereinigung) took place. East Germany became a part of the Federal Republic of Germany, and thereby 
East Germany disappeared as a member of the IAU. Since 1990, there is only one unified Germany as a member of the IAU. We expect that this is now the final solution for the long-standing problem of Germany's membership in the IAU!

Due to the disappearance of East Germany, the IAU lost the corresponding membership fee. Although the loss was rather small, many countries claimed that the future fee of the unified Germany should be the sum of the previous fees of West Germany and East Germany. However, the unified Germany remained in the old membership category (VII, 20 units) of West Germany, since this category was still adequate, even if based on the new, somewhat increased number of adhering astronomers (only the USA were in the then highest catagory VIII with 30 units). In any case, the German ministry financing the fee had made it very clear that it could not accept a significantly higher contribution of Germany than that which West Germany had paid before, because of all the other expenses caused by the reunification. The present author was the National Representative of the reunified Germany at the IAU General Assembly 1991 in Buenos Aires. When he communicated the point of view of Germany on its fee, this German position was criticized by some of his colleagues. They regretted that the basic IAU unit of contribution had to be increased (albeit very slightly, by about 4/1000 only) because of the loss of East Germany's fee (see Sadler 1962, p.113). Due to such a rise, all the other countries had then to pay (at least indirectly) for Germany's reunification!

The adhering organization of the reunified Germany for the IAU is the 'Rat Deutscher Sternwarten' (RDS), Council of German Observatories. In 2012, the RDS became an organ of the AG. Usually, the President of the AG is now simultaneously also the Chairman of the RDS.

\section{Conclusion}

We conclude our paper with a remarkable statement from Otto Struve (USA). He was President of the IAU from 1952 until 1955. In his speech (Oosterhoff 1954, p. 25), as President-Elect at the end of the IAU General Assembly 1952 in Rome, he said:

'...there was the admission of Germany. This action represented the healing of a wound which had threatened the very life of the Union from its beginning.'

\section{References}

Bergeron, J. (ed.) 1992, Transactions of the IAU, Vol. XXIB

Blaauw, A. 1994, History of the IAU. The Birth and First Half-Century of the International Astronomical Union. Kluwer Academic Publisher, Dordrecht / Boston / London, 296 p.

Dick, W. R. (ed.) 2000, Acta Historica Astronomiae, 10, 148

Fowler, A. (ed.) 1922, Transactions of the IAU, Vol. I

Freiesleben, H. C. 1962, Max Wolf: Der Bahnbrecher der Himmelsphotographie. 1863 - 1932. Wissenschaftliche Verlagsgesellschaft, Stuttgart, 241 p.

Gingrich, C. H. 1949, Popular Astronomy, 57, 307

Lüdtke, G. (ed.) 1933, Minerva. Jahrbuch der gelehrten Welt, 31. Jahrgang, 1933, 1. Abteilung, 1. Band (A-L), Forschungsinstitute, ... Walter de Gruyter, Berlin / Leipzig, p. 181

Lüdtke, G. (ed.) 1937, Minerva. Jahrbuch der gelehrten Welt, 32. Jahrgang, 1937, Abteilung Forschungsinstitute, ... Walter de Gruyter, Berlin / Leipzig, p. 130

Oort, J. H. (ed.) 1939, Transactions of the IAU, Vol. VI

Oort, J. H. (ed.) 1950, Transactions of the IAU, Vol. VII

Oosterhoff, P. Th. (ed.) 1954, Transactions of the IAU, Vol. VIII

Sadler, D. H. 1962, Transactions of the IAU, Vol. XIB

Schmeidler, F. (1988), Die Geschichte der Astronomischen Gesellschaft, Jubiläumsband 125 Jahre Astronomische Gesellschaft, Hamburg, 69 p.

Stratton, F. J. M. (ed.) 1933, Transactions of the IAU, Vol. IV

Stratton, F. J. M. (ed.) 1936, Transactions of the IAU, Vol. V 
Torge, W. (2007), Die Geschichte der Geodäsie in Deutschland. Walter de Gruyter, Berlin / New York, p. 295

Wielen, R., \& Wielen, U. 2012, Von Berlin über Sermuth nach Heidelberg. Das Schicksal des Astronomischen Rechen-Instituts in der Zeit von 1924 bis 1954 anhand von Schriftstücken aus dem Archiv des Instituts. Published in electronic form on the Open Access Platform HeiDOK of the University of Heidelberg (Universitätsbibliothek), 400 p. (with an abstract in English). www.ub.uni-heidelberg.de/archiv/14604, nbn-resolving.de/ urn:nbn:de:bsz:16-heidok-146043

Wielen, R., \& Wielen, U. 2013, August Kopff, die Relativitätstheorie, und zwei Briefe Albert Einsteins an Kopff im Archiv des Astronomischen Rechen-Instituts. Published in electronic form on the Open Access Platform HeiDOK of the University of Heidelberg (Universitätsbibliothek), 253 p. (with an abstract in English). www.ub.uniheidelberg.de/archiv/15653, nbn-resolving.de/urn:nbn:de:bsz:16-heidok-156534

Wielen, R., \& Wielen, U. 2016, Astronomische Ephemeriden, Navigation und Krieg. Die erstaunliche Zusammenarbeit der Ephemeriden-Institute von Deutschland, England, Frankreich und den USA im Zweiten Weltkrieg nach Dokumenten im Archiv des Astronomischen Rechen-Instituts. Published in electronic form on the Open Access Platform HeiDOK of the University of Heidelberg (Universitätsbibliothek), 253 p. (with an abstract in English). www.ub.uni-heidelberg.de/archiv/22021, nbn-resolving.de/ urn:nbn:de:bsz:16-heidok-220213 